ELORE (ISSN 1456-3010), vol. 20 - 2/2013.

Julkaisija: Suomen Kansantietouden Tutkijain Seura ry.

[http://www.elore.fi/arkisto/2_13/ojanen.pdf]

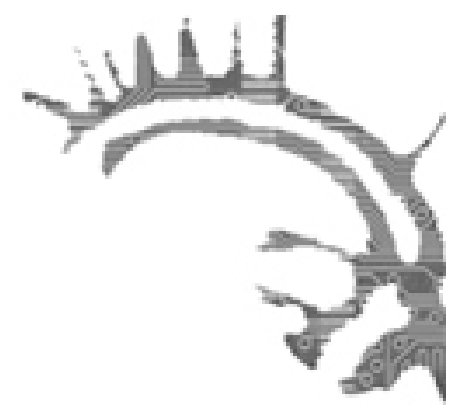

KirJa-ARViO

\title{
METALLIN MUSTA MAAILMA JA MASKULIINISUUKSIEN MALLIT
}

\author{
$\underline{\text { Karoliina Ojanen }}$
}

SARELIN, MIKAEL 2013: Krigaren och transvestiten. Gestaltningar av mörker och maskuliniteter i finländsk black metal. Abo: Abo Akademi University Press. 208 sivua.

Mikael Sarelinin väitöskirjassa käsitellään etnografisten aineistojen kautta black metal -musiikin kulttuurista näyttämöä. Black metallin harrastajat ja toimijat ovat suureksi osaksi miehiä, ja tutkimuksen perusteella kulttuuri on vielä mieskeskeisempi ja perinteisiä hegemonisen maskuliinisuuden malleja korostavampi kuin mitä hämärien ennakkokäsityksieni perusteella oletin. Sarelinin väitöskirja on hyvä johdatus metallimusiikin maailmaan ja sen vivahteikkaisiin käytäntöihin ja ideologioihin sekä neuvotteluihin sopivanlaisesta maskuliinisuudesta.

\section{FOLKLORISTISTA KRIITTISTÄ MIESTUTKIMUSTA}

Tutkimuksen tavoitteena on vastata kahteen kysymykseen. Ensiksi Sarelin tutkii pimeyden merkityksiä ja toiseksi maskuliinisuuksien muotoja black metal -kulttuurissa. 
Väitöskirjan aineisto on moninainen; se koostuu 11:stä noin 30-vuotiaan black metallin miespuolisen toimijan haastattelusta, konserttihavainnoinneista sekä muusta materiaalista kuten lyriikoista ja metallimusiikkilehdistä.

Väitöskirja on rakenteeltaan perinteinen lähtien kysymyksenasettelusta ja edeten kohti teoreettista viitekehystä, metodeja sekä hevimusiikin kulttuurisia taustoja. Sarelin kirjoittaa rehellisesti ja avoimesti aineiston hankkimisen eri vaiheista ja esimerkiksi sähköpostitse tehtyjen haastattelujen eduista ja haitoista. Metodeja käsittelevä luku päättyy pohdintaan tutkijan positioinnista ja refleksiivisyydestä, josta olisi mielellään lukenut enemmän myös sidottuna tiukemmin käytettyihin aineistoihin sekä tutkijan käsitykseen tutkimuksen kentästä.

Teorialuvussa on mainittu työssä käytetyt käsitteet ja kerrottu selkeästi, miten teoreettiset keskustelut on rajattu. Sarelin on väitellyt folkloristiikan alalta, ja tutkimus on monin tavoin folkloristisesti merkityksellinen, mutta viittauksia folkloristiikkaan löytyy lähinnä osiossa, jossa käsitellään pimeyden tematiikkaa piruineen. Sarelin ei positioi työtään suhteessa folkloristiseen pienryhmien tutkimuksen perinteeseen tai yleisemmin antropologiseen folkloristiikkaan, mikä olisi ollut mielenkiintoista. Sukupuolentutkimuksen osalta Sarelin liittää tutkimuksensa kriittiseen miestutkimukseen ja erityisesti keskusteluun maskuliinisuuksista. Keskeinen teoreetikko on Judith Butler ja keskeinen teoria hänen runsaasti sovellettu performatiivinen sukupuolenteoriansa. Butlerin teoria lukeutuu osaksi queer-tutkimusta, jonka Sarelin käsittelee erikseen. Kriittisen miestutkimuksen osalta Sarelin olisi voinut mahduttaa mukaan enemmän suomalaista mies- ja poikatutkimusta. Esimerkiksi kun Sarelin käsittelee black metal -kulttuurin väkivaltaisia ja rasistisia piirteitä, olisi ollut mielenkiintoista, jos hän olisi verrannut tulkintojaan Arto Jokisen (2000) tutkimukseen Panssaroitu maskuliinisuus. Jokisen tutkimuksessa käsitellään väkivallan merkitystä maskuliinisuuksien rakentumisessa esimerkiksi armeijan rasististen ja misogynististen epävirallisten laulujen kautta, joiden sanoituksissa näytti olevan samoja piirteitä kuin Sarelinin analysoimissa naisvihamielisissä lyriikoissa. Lisäksi esimerkiksi tutkimukset miesten moottoripyöräkulttuurin maskuliinisuuksista tai poikien kaahailukulttuurista käsittelevät nimenomaan maskuliinista homososiaalisuutta ja olisivat voineet tarjota antoisia näkökulmia ja kulttuurisia tarttumapintoja myös Sarelinin tutkimukselle. Ylipäätään tutkimukset homososiaalisista ryhmistä olisivat voineet lisätä Sarelinin tutkimuksen kulttuurista resonointia.

Sarelinin mukaan black metal -kulttuurin aiempi tutkimus on vähätellyt sukupuolen merkitystä. Sarelin puolestaan osoittaa vakuuttavasti, miten keskeisellä tavalla tämä kulttuurinen näyttämö järjestyy seuraten nimenomaan käsityksiä sukupuolista. Sarelin tuo esille black metallin perinteisen, dikotomisen sukupuolijärjestyksen, jossa hieman kärjistäen miehet toimivat ja soittavat kun naisten paikka on hoivatehtävissä kotona. Käsityksiä sukupuolten ominaisuuksista olisi voinut olla mielenkiintoista suhteuttaa myös suomalaiseen tasa-arvoideologiaan. Sarelin tuo esille esimerkiksi analysoidessaan haastateltavien näkemyksiä toiminnan miesvaltaisuudesta, että joidenkin miesten mielestä naiset voisivat periaatteessa olla enemmän mukana toiminnassa. Toisaalta miesten mielestä naisilta puuttuu tarvittava sitoutuminen black metallin ideologioihin ja lisäksi reproduktiivisten tehtävien vuoksi heillä ei ole aikaa vaaditunlaiseen omistautumiseen. Miten tämäntyyppiset ristiriitaisuudet ovat suhteessa suomalaiseen tasa-arvoilmas- 
toon? Miehet asettavat vastauksensa yhtäältä siten, että he ovat yhteiskuntamme tasaarvoideologiasta tietoisia (naisetkin voisivat tulla mukaan) ja toisaalta miehet samalla legitimoivat kulttuurin "omana tilanaan" toteamalla, että naisilta puuttuvat black metal -kulttuurissa tarvittavat ominaisuudet. Tämäntyyppinen puhe muistutti minua tallityttöjen homososiaalisen yhteisön puhetavoista: pojat yhtäältä toivotettiin tervetulleiksi ja toisaalta samalla todettiin, että pojat eivät kuitenkaan pidä hoivaamisesta eivätkä osaa letittää kuten tytöt. Tallitytöt eivät ole lähellä Sarelinin tutkimuskohdetta, eivätkä varmasti ole olennaisin vertailukohde sille, mutta yleisesti ottaen homososiaalisia yhteisöjä koskevasta tutkimuksesta olisi voinut olla jotain iloa black metal -näyttämön toimintatapojen ja logiikan hahmottamisessa.

\section{Pimeän maskulinisisudet?}

Kuten sanottua, Sarelinin analyysi jakautuu kahteen teemaan, joista ensimmäinen on koko black metal -ilmiötä, sen musiikkia, esitystapoja ja ideologiaa, läpileikkaava pimeys. Pimeys saa ilmaisunsa useimmiten antikristillisyytenä, ja on keskeinen osa black metallin tyyliä. Pimeyttä analysoidessaan Sarelin tarkastelee myös esimerkiksi kansallisromanttisuutta tämän musiikkikulttuurin yhtenä piirteenä. Olisiko pimeyden tematiikkaa voinut analysoida lisää suhteessa yhteiskunnalliseen kontekstiin? Sarelin mainitsee yhteiskuntakriittisyyden osana black metal -kulttuurin eetosta ja hän toteaa, että kulttuurille on tyypillistä yksilökeskeisyyden painottaminen. Esimerkiksi näistä seikoista olisi ollut mielenkiintoista lukea enemmänkin maskuliinisuuksien rakentumisen näkökulmasta. Ylipäätään olisi ollut kiehtovaa, jos Sarelin olisi käsitellyt yhteiskunnallista kontekstia ja yhteiskuntakriittisyyttä vielä syvemmin suhteessa hänen ansiokkaasti analysoimiinsa maskuliinisuuksien malleihin. Esimerkiksi keskustelu nuorten maskuliinisuuksien kriisistä olisi saattanut laajentaa Sarelinin tutkimuksessa tehtyjä havaintoja. Sarelin on käsitellyt pimeyden ja maskuliinisuuksien teemat tarkoituksellisesti omina kokonaisuuksinaan, mutta tässä kohtaa pohdin, olisiko niitä voinut keskusteluttaa analyysissa saumattomammin toisiinsa kietoutuneina ilmiöinä.

Itseäni kiinnosti erityisesti Sarelinin toinen analyysikohde eli maskuliinisuuksien käsitteellistäminen ja analysointi. Sarelinin mukaan maskuliinisuudet saavat muotonsa pukeutumistyyleissä, sanoissa ja eleissä. Sarelin painottaa maskuliinisuuksien moninaisuutta: yhtäl̈lä jokaisen toimijan maskuliinisuus on erityinen, mutta toisaalta hän nimeää black metal -kulttuurille kaksi keskeistä maskuliinisuuden mallia tutkimuksen otsikon mukaisesti: soturit ja transvestiitit. Soturit edustavat normatiivista maskuliinisuuden mallia, johon kuuluu tietty äijämentaliteetti, jota Sarelin analysoi kiinnostavasti. Soturit Sarelin jakaa vielä barbaareihin ja natsimielisiin. Soturit ilmentävät protestimaskuliinisuutta edustaen black metal -kulttuurin läpileikkaavaa yhteiskuntakriittisyyttä, joka on voitu ymmärtää myös "sotana kristinuskoa vastaan". Soturi-maskuliinisuudessa korostuu heteronormatiivisuus, väkivallan ihannointi, fyysinen voima, aggressiivisuus, patriarkaalisuus ja ylipäätään miehinen valta.

Toisen maskuliinisuuden mallin Sarelin on nimennyt transvestiitiksi, joka samaten on tulkittavissa yhteiskuntakriittiseksi maskuliinisuuden malliksi, mutta 
myös kriittiseksi puheenvuoroksi black metal -kulttuurin heteronormatiivista sukupuolijärjestelmää kohtaan. Tällaisen maskuliinisuuden edustajiksi Sarelin on nimennyt kaksi yhtyettä, joiden jäsenet käyttävät esiintyessään kulttuurissamme feminiinisiksi määriteltyjä merkkejä, kuten meikkiä tai korsettia. Tähän maskuliinisuuden muotoon suhtaudutaan kuitenkin yhteisön sisällä ristiriitaisesti. Sarelin kertoo konsertista, jossa hän kuuli jonkun kutsuvan tällaisen yhtyeen esiintymistä "homojen hommaksi", mikä ilmentää black metal -kulttuurille tavallista heteronormatiivisuutta homofobioineen. Sarelin käsittelee tätä maskuliinisuuden mallia kiinnostavasti kuvatessaan esimerkiksi esiintymistilannetta, jossa yhtyeen jäsen tulee lavalle pukeutuneena pikkutytöksi, joka työntää punaisia nukenrattaita. Esityksen aikana tytöksi pukeutunut mies sivelee itsensä punaisella nesteellä. Sarelin tulkitsee esityksen sekä haastavan menstruaatioon liittyviä tabuja että vihjaavan insestiin ja pedofiliaan. Hänen mukaansa tämä tuottaa erilaisia rajoja ylittävän ja sekoittavan "cocktailin".

Aineistoesimerkit sekä haastatteluista että havainnoinneista olivat todella mielenkiintoisia. Ne avasivat tutkittavaa maailmaa hyvin ja niitä olisi ollut ilahduttavaa lukea enemmän.

\section{LOPUKSI}

Tartuin Sarelinin väitöskirjaan suurella innolla koska olen aiemmin tutkinut tallityttöjen homososiaalista yhteisöä, koska nyttemmin olen kiinnostunut maskuliinisuuksien tutkimuksesta ja koska en tiedä metallimusiikin kulttuurisesta näyttämöstä juuri mitään. Sarelinin teos on asiaa täysin tuntemattomalle mielenkiintoinen sukellus maailmaan, joka pyrkii shokeeraamaan ja joka monissa kohdin asettuu vastoin yhteiskuntamme vallitsevia moraali- ja arvokäsityksiä. Tutkimus on arvokas avaus lisäksi siitä näkökulmasta, että se valottaa sellaisen miesten homososiaalisen yhteisön tutkimusta, jossa toimii myös normeja kyseenalaistavia maskuliinisuuksien malleja. Black metal -kulttuurin hegemoninen maskuliinisuuden malli on yhdistelmä heteronormatiivisuutta, aggressiota, fyysistä voimaa, itsenäisyyttä ja riippumatonta oman elämänsä herruutta, mutta sen vierellä toimii myös tätä mallia horjuttava maskuliinisuuden käytäntö.

\section{KirJallisuUs}

JOKINEN, ARTO 2000: Panssaroitu maskuliinisuus. Mies, väkivalta ja kulttuuri. Tampere: Tampereen yliopistopaino.

KINNARINEN, KIRSI 2005: Mies, talli ja moottoripyörä. Pro gradu -tutkielma. Helsinki: Helsingin yliopisto.

NAYAK, ANOOP \& KEHILY, MARY JANE 2008: Gender, youth and culture. Young masculinities and femininities. New York: Palgrave MacMillan. 
Karoliina Ojanen: Metallin musta maailma ja maskuliinisuuksien mallit

VAARANEN, HELI 2004: Kaaharipoikia ja rappioromantiikkaa: Tutkimus erä̈̈n kaahailukulttuurin elämänilosta ja tuhoisuudesta. Helsinki: Yhdyskuntasuunnittelun tutkimus- ja koulutuskeskus.

Filosofian tohtori Karoliina Ojanen toimii tutkijatohtorina Helsingin yliopistossa. 